\title{
Enhanced Electroreductive Removal of Bromate by a Supported Pd-In Bimetallic Catalyst: Kinetics and Mechanism Investigation
}

\author{
Huachun Lan, Ran Mao, Yating Tong, Yanzhen Liu, Huijuan Liu, Xiaoqiang An, and Ruiping Liu* \\ Key Laboratory of Drinking Water Science and Technology, Research Center for Eco-Environmental Sciences, Chinese Academy of \\ Sciences, Beijing 100085, China
}

\section{Supporting Information}

ABSTRACT: In this work, the electroreductive removal of bromate by a $\mathrm{Pd}_{1}-\mathrm{In}_{4} / \mathrm{Al}_{2} \mathrm{O}_{3}$ catalyst in a three-dimensional electrochemical reactor was investigated. A total of $96.4 \%$ of bromate could be efficiently reduced and completely converted into bromide within $30 \mathrm{~min}$ under optimized conditions. On the basis of the characterization results and kinetics analysis, a synergistic effect of $\mathrm{Pd}$ and $\mathrm{In}$ was observed, and $\mathrm{Pd}_{1}-\mathrm{In}_{4} / \mathrm{Al}_{2} \mathrm{O}_{3}$ had the highest reaction rate constant of $0.1275 \mathrm{~min}^{-1}$ (vs $0.0413,0.0328$, and $0.0253 \mathrm{~min}^{-1}$ for $\mathrm{In} / \mathrm{Al}_{2} \mathrm{O}_{3}, \mathrm{Pd} / \mathrm{Al}_{2} \mathrm{O}_{3}$, and $\mathrm{Al}_{2} \mathrm{O}_{3}$ ). The results of electron spin resonance and scavenger experiments confirmed that both direct electron transfer and indirect reduction by atomic $\mathrm{H}^{*}$ were involved in the bromate removal process, while the direct reduction played a more important role. Moreover, the introduction of In could increase the zeta potential of $\mathrm{Pd}_{1}-\mathrm{In}_{4} / \mathrm{Al}_{2} \mathrm{O}_{3}$, facilitating bromate adsorption and its subsequent reduction on the catalyst. Finally, a reaction mechanism for bromate reduction by $\mathrm{Pd}_{1}-\mathrm{In}_{4} / \mathrm{Al}_{2} \mathrm{O}_{3}$ was proposed based on all the experimental results.

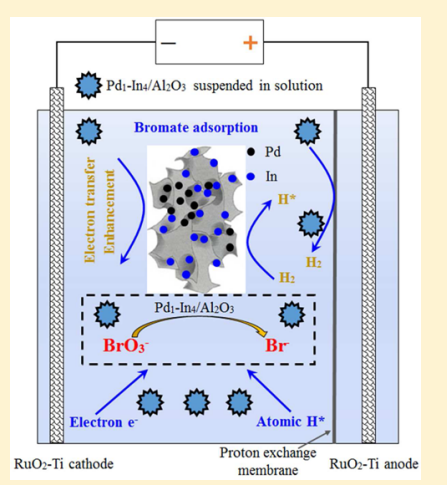

\section{INTRODUCTION}

Bromate is an oxyhalide disinfection byproduct frequently detected in drinking water from ozonation of bromidecontaining source waters. ${ }^{1}$ Because of its carcinogenic and genotoxic properties, the World Health Organization (WHO) has promulgated a $10 \mu \mathrm{g} / \mathrm{L}$ standard for bromate in drinking water. ${ }^{2}$ To meet this strict limitation, numerous treatment methods have been explored, including filtration, chemical reduction, biodegradation, activated carbon techniques, and photocatalysis. $^{3-8}$ Among these technologies, liquid phase catalytic hydrogenation has proven to be an efficient and clean method to eliminate bromate. ${ }^{9,10}$ Wang et al. reported the hydrogenation reduction of bromate using a core-shell-structured catalyst with encapsulated Pd nanoparticles. ${ }^{11}$ However, the catalytic hydrogenation needs an external supply of $\mathrm{H}_{2}$, while the storage and transportation of $\mathrm{H}_{2}$ may be a hidden danger. Alternatively, the electrochemical reduction of bromate is found to be a promising approach due to its low maintenance requirements and efficient minimization of toxic chemicals and secondary pollution. ${ }^{12-14}$ Kishimoto and Matsuda reported an efficient electrochemical method to reduce bromate to bromide using a two-compartment electrolytic flow cell with activated carbon felt as electrodes. ${ }^{15}$ The results showed that bromate contamination can be removed within a few minutes, but this process required acidic conditions. Zhao et al. studied the effectiveness of a boron-doped diamond electrode in bromate removal by electrochemical reduction, and nearly $90 \%$ of bromate could be removed with the bias potential of $-1.0 \mathrm{~V}$ within $2 \mathrm{~h}^{14}$ However, the application of these cathodes for water treatment would be limited due to the low $\mathrm{A} / \mathrm{V}$ ratio (ratio of the electrode area and solution volume). Hence, it is necessary to design a new electrochemical reactor and electrode with high efficiency. Recently, a three-dimensional electrochemical reactor using granular activated carbon (GAC) or modified GAC as particle electrodes exhibited higher efficiency in treatment of heavy oil refinery wastewater compared with a two-dimensional electrode reactor (without particles). ${ }^{16}$ Moreover, the removal rate of the target pollutants could also be increased by using three-dimensional electrodes with more available reactive sites and electrons compared to the conventional two-dimensional electrodes. ${ }^{17,18}$

It is widely reported that $\mathrm{Pd}$ has the unique property of activating $\mathrm{H}_{2}$ to produce continuously adsorbed atomic $\mathrm{H}^{*}$ and trapping electrons, which could serve as a strong reducing agent in catalytic reductive reactions. ${ }^{19}$ Moreover, Pd-based bimetallic catalysts were found to exhibit better activity and selectivity in many important chemical reactions compared with monometallic Pd catalysts. ${ }^{20-22}$ It has been reported that the enhanced catalytic activity could be attributed to the promotion effect of the second metal element such as $\mathrm{Cu}, \mathrm{Au}, \mathrm{Bi}, \mathrm{Sn}, \mathrm{Fe}$, etc. ${ }^{23-27}$ For instance, the catalytic hydrogenation efficiency of $\mathrm{Pd} / \mathrm{SnO}_{2}$ and $\mathrm{Pd} / \mathrm{Al}_{2} \mathrm{O}_{3}$ toward $\mathrm{N}$-nitrosodimethylamine and nitrate reduction was greatly enhanced by the addition of $\mathrm{Sn}$ and $\mathrm{In}^{28,29}$ The efficiency of $\mathrm{Cu}$ - and $\mathrm{Sn}$-doped carbon nanofiber/sintered metal fiber filters was also evaluated by bromate and nitrate reduction in continuously operated reactors. ${ }^{30}$ However, studies on the electroreduction of bromate in a three-dimensional electrochemical reactor by $\mathrm{Pd}$-based three-dimensional suspended electrodes are still limited. In addition, the effect of the dosage of

Received: June 25, 2016

Revised: September 18, 2016

Accepted: September 30, 2016

Published: September 30, 2016 
other transition-metal $(\mathrm{Cu}, \mathrm{Sn}, \mathrm{Bi}$, and $\mathrm{In})$ dopants on the catalytic activity of Pd also needs to be investigated.

Hence, in this study, different Pd-based supported catalysts ( $\mathrm{Pd}-\mathrm{M} / \mathrm{Al}_{2} \mathrm{O}_{3}, \mathrm{M}=\mathrm{Cu}, \mathrm{Sn}, \mathrm{Bi}$ and In) were synthesized for the first time and evaluated based on their bromate reduction efficiency. $\mathrm{Pd}_{1}-\mathrm{In}_{4} / \mathrm{Al}_{2} \mathrm{O}_{3}$ was proven to have the highest efficiency as particle electrodes in the electrochemical reductive removal of bromate in a three-dimensional electrochemical reactor. Moreover, the bromate reduction followed pseudo-first-order kinetics. The catalyst was further characterized by X-ray powder diffraction (XRD), transmission electron microscopy (TEM), Brunauer-Emmett-Teller (BET), X-ray photoelectron spectroscopy (XPS), and zeta potential analysis to study the synergistic effect of $\mathrm{Pd}$ and In within the catalyst. The effect of catalyst dosage, solution $\mathrm{pH}$, and applied current on the bromate reduction over $\mathrm{Pd}_{1}-\mathrm{In}_{4} / \mathrm{Al}_{2} \mathrm{O}_{3}$ was also studied in detail. On the basis of electron spin resonance (ESR) scavenger experiments, both direct electron transfer and indirect reduction by atomic $\mathrm{H}^{*}$ were confirmed to be involved in the bromate removal process. Finally, an electrochemical reduction mechanism of bromate over $\mathrm{Pd}_{1}-\mathrm{In}_{4} / \mathrm{Al}_{2} \mathrm{O}_{3}$ was proposed according to all the experimental results. The findings in this study demonstrate the potential of the three-dimensional electrochemical reactor as an effective system for eliminating bromate contamination in water.

\section{MATERIALS AND METHODS}

The catalysts were prepared by a conventional impregnation method. Briefly, $\gamma$ - $\mathrm{Al}_{2} \mathrm{O}_{3}$ was immersed in $\mathrm{PdCl}_{2}$ solution containing $0.1 \mathrm{M}$ hydrochloric acid, followed by ultrasonic treatment for $360 \mathrm{~min}$. After standing for $24 \mathrm{~h}$, the obtained samples were dried at $120{ }^{\circ} \mathrm{C}$, calcined at $300{ }^{\circ} \mathrm{C}$ for $120 \mathrm{~min}$, and finally reduced at $200{ }^{\circ} \mathrm{C}$ in a $\mathrm{H}_{2}$ atmosphere for $300 \mathrm{~min}$ (flow rate: $100 \mathrm{~mL} / \mathrm{min}$ ). The resulting supported Pd catalysts were denoted as $x \% \mathrm{Pd} / \mathrm{Al}_{2} \mathrm{O}_{3}$, where $x$ is the Pd loading amount (wt \%). Bimetallic $\mathrm{Pd}-\mathrm{M} / \mathrm{Al}_{2} \mathrm{O}_{3}$ catalysts $(\mathrm{M}=\mathrm{In}, \mathrm{Cu}, \mathrm{Sn}, \mathrm{Bi})$ were obtained by the same impregnation method with the theoretical $\mathrm{Pd} / \mathrm{M}$ ratio of $1: 4 . \mathrm{Pd}-\mathrm{In} / \mathrm{Al}_{2} \mathrm{O}_{3}$ with different $\mathrm{Pd} / \mathrm{In}$ ratios was denoted as $\mathrm{Pd}_{x}-\mathrm{In}_{y} / \mathrm{Al}_{2} \mathrm{O}_{3}$, where $x / y$ is the theoretical $\mathrm{Pd} / \mathrm{In}$ ratio.

A three-dimensional electrochemical reactor was used for the electrochemical experiments, which was separated into a cathode cell and anode cell by a proton-exchange membrane (Nafion117, Dupont). For each batch experiment, the cathode cell was filled with $50 \mathrm{~mL}$ of aqueous solution of bromate using $\mathrm{Na}_{2} \mathrm{SO}_{4}$ as the supporting electrolyte. $\mathrm{RuO}_{2} / \mathrm{Ti}$ was used as the cathode and anode with an effective geometric surface area of $100 \mathrm{~cm}^{2}$, and the distance between cathode and anode was $4 \mathrm{~cm}$. The reactor was controlled by a DC power supply source AMERLLPS302A (Dahua instrument corporation of Beijing). The initial concentration of bromate was $100 \mu \mathrm{g} / \mathrm{L}$ unless otherwise specified, and the experiments were performed at room temperature. The system was magnetically stirred at a rate of $800 \mathrm{rpm}$.

The concentrations of bromate and bromide were measured using a Dionex 2000 ion chromatograph (IC), equipped with an IonPac AS-19 anion-exchange analytical column, an IonPac AG19 guard column, and $\mathrm{KOH}$ solution as mobile phase eluent. Atomic $\mathrm{H}^{*}$ signals were measured on a Bruker model ESR 300E spectrometer, with a Quanta-Ray Nd:YAG laser system as the irradiation source and 5,5'-dimethyl-1-pirroline-N-oxide (DMPO) as the spin-trap reagent. XRD patterns of the catalysts were recorded with an X'Pert PRO powder diffractometer (PANalytical Co.). TEM images and energy dispersive spectrometer (EDS)
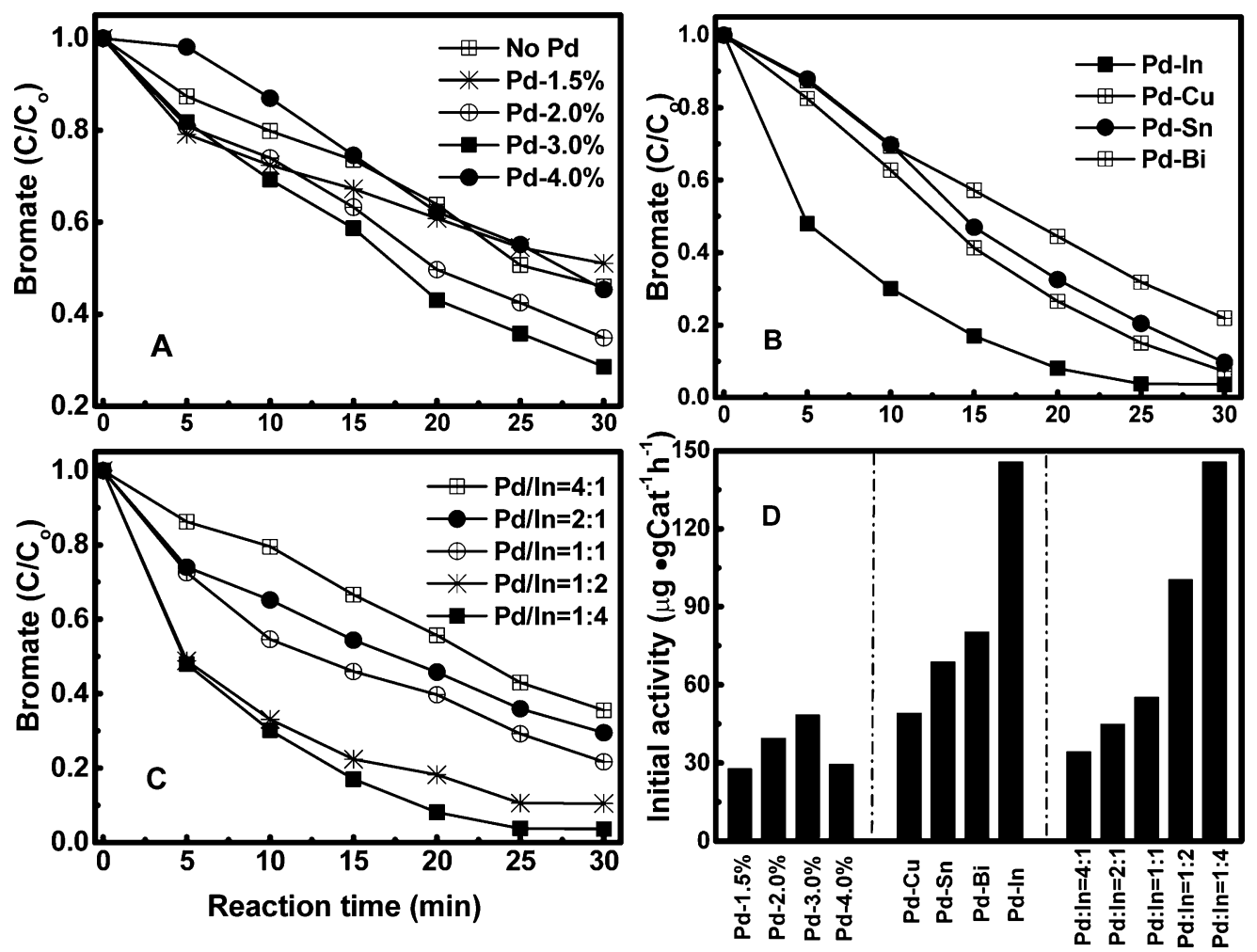

Figure 1. (A) Effect of Pd loading, (B) cometals, and (C) Pd/In ratio on the electrochemical reduction of bromate. (D) Initial activity of the catalyst under varying conditions (catalyst dosage $=1.0 \mathrm{~g} / \mathrm{L}, \mathrm{Pd}$ content of the catalysts in B and C was $3.0 \%$, initial bromate concentration $=100 \mu \mathrm{g} / \mathrm{L}, 2 \mathrm{mM}$ $\mathrm{Na}_{2} \mathrm{SO}_{4}, \mathrm{pH}=7.0$, current density $=0.9 \mathrm{~mA} / \mathrm{cm}^{2}$ ). 
images of the samples were obtained on a transmission electron microscope, JEM-2100F Field Emission Electron Microscope (JEOL Ltd.). XPS analysis was carried out with a Kratos AXIS Ultra X-ray photoelectron spectrometer. The specific surface area measurement was performed using the BET method using a surface area analyzer, ASAP 2020 HD88 (Micromeritics Co.). The surface potential of the samples was characterized by a Nano Particle Sizing and Zeta Potential Analyzer (DelsaNano C, Beckman Coulter Ltd.).

\section{RESULTS AND DISCUSSION}

Efficient Electroreduction of Bromate by $\mathrm{Pd}_{1}-\mathrm{In}_{4} /$ $\mathrm{Al}_{2} \mathrm{O}_{3}$ Catalyst. The effect of $\mathrm{Pd}$ loading on $\mathrm{Al}_{2} \mathrm{O}_{3}$ on the bromate reduction was optimized first. As shown in Figure 1A, the removal efficiency of bromate increased to a maximum value, and then decreased with increasing $\mathrm{Pd}$ content (the initial activity of $\mathrm{Pd} / \mathrm{Al}_{2} \mathrm{O}_{3}$ was $27.74,39.48,48.36$, and $29.4 \mu \mathrm{g} \cdot \mathrm{gCat}^{-1} \cdot \mathrm{h}^{-1}$ when Pd content was $1.5 \%, 2.0 \%, 3.0 \%$, and $4.0 \%$, Figure $1 \mathrm{D})$. Higher amounts of Pd will aggregate on the surface of $\mathrm{Al}_{2} \mathrm{O}_{3}$, which may result in locally excessive $\mathrm{H}_{2}$ evolution ${ }^{31}$ and then inhibit the $\mathrm{H}_{2}$ efficiency by restricting the access of bromate to the interior $\mathrm{H}_{2}$ generation sites. $\mathrm{Cu}, \mathrm{Sn}, \mathrm{Bi}$, and $\mathrm{In}$ as the promoting metals for $\mathrm{Pd}-\mathrm{M} / \mathrm{Al}_{2} \mathrm{O}_{3}$ were chosen, and their efficiency was also evaluated based on bromate reduction (Figure 1B). Compared with $\mathrm{Pd} / \mathrm{Al}_{2} \mathrm{O}_{3}$, all the bimetal catalysts exhibited an improved electroreduction activity with the order of $\mathrm{Pd}-\mathrm{Cu}$ / $\mathrm{Al}_{2} \mathrm{O}_{3}<\mathrm{Pd}-\mathrm{Sn} / \mathrm{Al}_{2} \mathrm{O}_{3}<\mathrm{Pd}-\mathrm{Bi} / \mathrm{Al}_{2} \mathrm{O}_{3}<\mathrm{Pd}-\mathrm{In} / \mathrm{Al}_{2} \mathrm{O}_{3}$ (the initial activity was $49.12,68.86,80.24$, and $145.58 \mu \mathrm{g} \cdot \mathrm{gCat}^{-1} \cdot \mathrm{h}^{-1}$, respectively, Figure $1 \mathrm{D}) . \mathrm{Pd}-\mathrm{In} / \mathrm{Al}_{2} \mathrm{O}_{3}$ had the highest activity toward bromate reduction, and the optimal atomic ratio of Pd to In was further evaluated. As depicted in Figure 1C, the electroreduction rate of bromate increased dramatically with In content, and the initial activity of $\mathrm{Pd}-\mathrm{In} / \mathrm{Al}_{2} \mathrm{O}_{3}$ was 34.26, 44.9, $55.24,100.42$, and $145.58 \mu \mathrm{g} \cdot \mathrm{gCat}^{-1} \cdot \mathrm{h}^{-1}$ with a $\mathrm{Pd} / \mathrm{In}$ ratio of
4:1, 2:1, 1:1, 1:2 and 1:4 (Figure 1D). Hence, $\mathrm{Pd}_{1}-\mathrm{In}_{4} / \mathrm{Al}_{2} \mathrm{O}_{3}$ with a Pd loading amount of $3.0 \%$ was chosen in the subsequent experiments.

In addition, the bromate electroreduction and the generation of bromide were further investigated for different particle electrode materials, and the obtained results were found to follow pseudo-first-order kinetics. As shown in Figure 2, the bromate concentration decreased by $54.0 \%, 64.2 \%$, and $71.4 \%$ in the presence of $\mathrm{Al}_{2} \mathrm{O}_{3}, \mathrm{In} / \mathrm{Al}_{2} \mathrm{O}_{3}$, and $\mathrm{Pd} / \mathrm{Al}_{2} \mathrm{O}_{3}$, while about $96.4 \%$ of bromate was reduced at $30 \mathrm{~min}$ with $\mathrm{Pd}_{1}-\mathrm{In}_{4} / \mathrm{Al}_{2} \mathrm{O}_{3}$. That is to say, when the initial concentration of bromate was $100 \mu \mathrm{g} / \mathrm{L}$, the remaining bromate in solution was only $3.6 \mu \mathrm{g} / \mathrm{L}$, which was much lower than the standard of $10 \mu \mathrm{g} / \mathrm{L}$. Moreover, the reaction rate constant of $\mathrm{Pd}_{1}-\mathrm{In}_{4} / \mathrm{Al}_{2} \mathrm{O}_{3}$ was $0.1275 \mathrm{~min}^{-1}$, which was also much higher than that of other catalysts $(0.0413,0.0328$, and $0.0253 \mathrm{~min}^{-1}$ for $\mathrm{Pd} / \mathrm{Al}_{2} \mathrm{O}_{3}, \mathrm{In} / \mathrm{Al}_{2} \mathrm{O}_{3}$, and $\left.\mathrm{Al}_{2} \mathrm{O}_{3}\right)$. It was worthy to note that the reaction constants for bromide formation were a little lower than that for bromate reduction $(0.099,0.0371$, 0.0278 , and $0.0215 \mathrm{~min}^{-1}$ ). The bromine balance will be analyzed subsequently. The above results indicated that a synergistic effect of Pd and In existed within the catalyst and that it could enhance the current efficiency (as shown in Figure S1, the electric energy consumption to remove $1 \mathrm{mg}$ bromate was 0.0065 , 0.0105, 0.0127, and 0.0166 KWh for $\mathrm{Pd}_{1}-\mathrm{In}_{4} / \mathrm{Al}_{2} \mathrm{O}_{3}, \mathrm{Pd} / \mathrm{Al}_{2} \mathrm{O}_{3}$, $\mathrm{In} / \mathrm{Al}_{2} \mathrm{O}_{3}$, and $\mathrm{Al}_{2} \mathrm{O}_{3}$, respectively). Hence, $\mathrm{Pd}_{1}-\mathrm{In}_{4} / \mathrm{Al}_{2} \mathrm{O}_{3}$ was proven to be an ideal particle electrode material for the removal of bromate in water by electroreduction.

Characterization of $\mathrm{Pd}_{1}-\mathrm{In}_{4} / \mathrm{Al}_{2} \mathrm{O}_{3}$. The changes of physicochemical properties responsible for the higher efficiency of $\mathrm{Pd}_{1}-\mathrm{In}_{4} / \mathrm{Al}_{2} \mathrm{O}_{3}$ were characterized by TEM, XRD, BET, and XPS analysis. As depicted in Figure $3 \mathrm{~A}$ and $\mathrm{B}$, the lattice spacing of $0.228 \mathrm{~nm}$ belonged to the $\operatorname{Pd}(111)-\operatorname{In}(111)$ bimetal. The average metal particle size was found to be ca. $7.7 \mathrm{~nm}$. The measured ratio of $\mathrm{Pd} / \mathrm{In}$ at different sites of the composite was
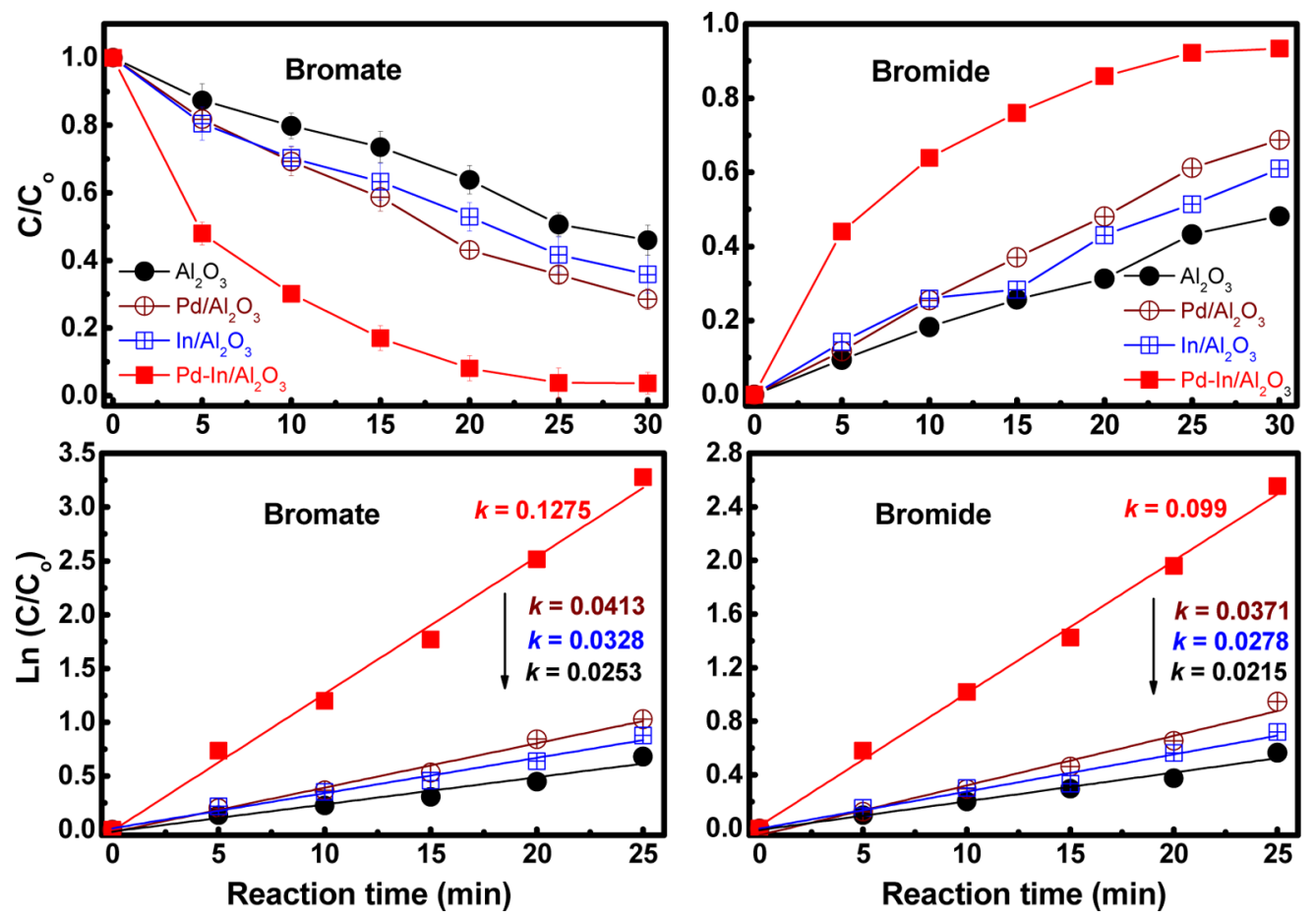

Figure 2. Electrochemical reduction of bromate and the generation of bromide with different catalysts (catalyst dosage $=1.0 \mathrm{~g} / \mathrm{L}$, initial bromate concentration $=100 \mu \mathrm{g} / \mathrm{L}, 2 \mathrm{mM} \mathrm{Na}_{2} \mathrm{SO}_{4}, \mathrm{pH}=7.0$, current density $\left.=0.9 \mathrm{~mA} / \mathrm{cm}^{2}\right)$. 

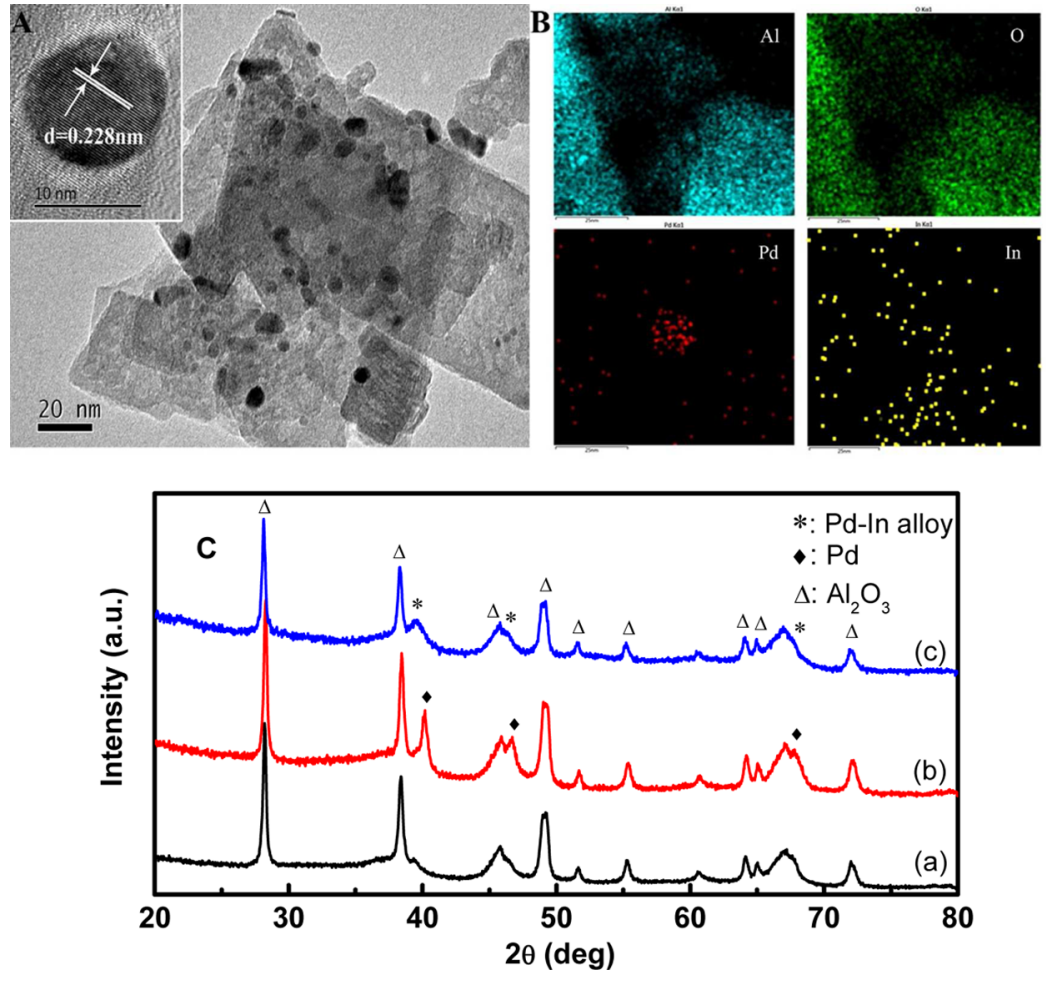

Figure 3. (A) TEM image of $\mathrm{Pd}_{1}-\mathrm{In}_{4} / \mathrm{Al}_{2} \mathrm{O}_{3}$. (B) EDX images for $\mathrm{Pd}_{1}-\mathrm{In}_{4} / \mathrm{Al}_{2} \mathrm{O}_{3}$ element mapping, and (C) XRD patterns of (a) $\mathrm{Al}_{2} \mathrm{O}_{3}$, (b) $\mathrm{Pd} / \mathrm{Al}_{2} \mathrm{O}_{3}$, and $(\mathrm{c}) \mathrm{Pd}_{1}-\mathrm{In}_{4} / \mathrm{Al}_{2} \mathrm{O}_{3}$.

determined to be from 1:2.78 to 1:4.96. Additionally, Pd particles aggregated to some extent, while In was highly dispersed on the surface of $\mathrm{Al}_{2} \mathrm{O}_{3}$. The diffraction peaks assigned to the (111), (200), and (220) reflections of metallic Pd were observed for the $\mathrm{Pd} / \mathrm{Al}_{2} \mathrm{O}_{3}$ catalyst (Figure $3 \mathrm{C}$ ), reflecting the typical face centered cubic crystallographic structure, ${ }^{10}$ while the new peak at $39.6^{\circ}$ can be attributed to the $\mathrm{Pd}-$ In alloy. ${ }^{32}$ Table 1 shows the

\section{Table 1. BET Results for Different Catalysts}

\begin{tabular}{lccc} 
& $\begin{array}{c}\text { BET area } \\
\left(\mathrm{m}^{2} / \mathrm{g}\right)\end{array}$ & $\begin{array}{c}\text { pore volume } \\
\left(\mathrm{cm}^{3} / \mathrm{g}\right)\end{array}$ & $\begin{array}{c}\text { pore size } \\
(\mathrm{nm})\end{array}$ \\
$\mathrm{Al}_{2} \mathrm{O}_{3}$ & 67.97 & 0.27 & 15.65 \\
$\mathrm{Pd} / \mathrm{Al}_{2} \mathrm{O}_{3}$ & 63.70 & 0.34 & 21.27 \\
$\mathrm{Pd}-\mathrm{In} / \mathrm{Al}_{2} \mathrm{O}_{3}(4: 1)$ & 74.62 & 0.35 & 19.13 \\
$\mathrm{Pd}-\mathrm{In} / \mathrm{Al}_{2} \mathrm{O}_{3}(1: 4)$ & 41.90 & 0.22 & 21.31 \\
\hline
\end{tabular}

BET results for different catalysts. The average pore size of the mesoporous $\mathrm{Al}_{2} \mathrm{O}_{3}$ was $15.65 \mathrm{~nm}$, which was larger than the size of the metal nanoparticles $(7.7 \mathrm{~nm})$. The BET area and pore volume were similar for $\mathrm{Al}_{2} \mathrm{O}_{3}, \mathrm{Pd} / \mathrm{Al}_{2} \mathrm{O}_{3}$, and $\mathrm{Pd}_{4}-\mathrm{In}_{1} / \mathrm{Al}_{2} \mathrm{O}_{3}$. However, a significant decrease of $\mathrm{BET}$ area and pore volume was observed for $\mathrm{Pd}_{1}-\mathrm{In}_{4} / \mathrm{Al}_{2} \mathrm{O}_{3}\left(42 \mathrm{~m}^{2} / \mathrm{g}\right.$ and $0.22 \mathrm{~cm}^{3} / \mathrm{g}$ vs $64-74 \mathrm{~m}^{2} / \mathrm{g}$ and $0.34-0.35 \mathrm{~cm}^{3} / \mathrm{g}$ ), which meant that some of the loaded metals might have occupied the volume in the mesopores. This result indicates that the specific surface area was not a critical factor for the high activity of $\mathrm{Pd}_{1}-\mathrm{In}_{4} / \mathrm{Al}_{2} \mathrm{O}_{3}$. In addition, the impact of In introduction on the valence state of $\mathrm{Pd}$ was studied by XPS (Figure 4). With the increase of In loading $\left(\mathrm{Pd}, \mathrm{Pd}_{4}-\mathrm{In}_{1}\right.$, and $\left.\mathrm{Pd}_{1}-\mathrm{In}_{4}\right)$, the binding energy of $\mathrm{Pd}_{3 \mathrm{~d}}$ shifted toward a higher value from $334.4 \mathrm{eV}\left(3 \mathrm{~d}_{5 / 2}\right)$ and $339.7 \mathrm{eV}\left(3 \mathrm{~d}_{3 / 2}\right)$ to 334.8 and $340.0 \mathrm{eV}$ and 335.8 and $341.1 \mathrm{eV}$. Meanwhile, the position of the peak assigned to In (0), with a binding energy of $444.79 \mathrm{eV}\left(3 \mathrm{~d}_{5 / 2}\right)$ and $452.39 \mathrm{eV}\left(3 \mathrm{~d}_{3 / 2}\right)$, did not change with In
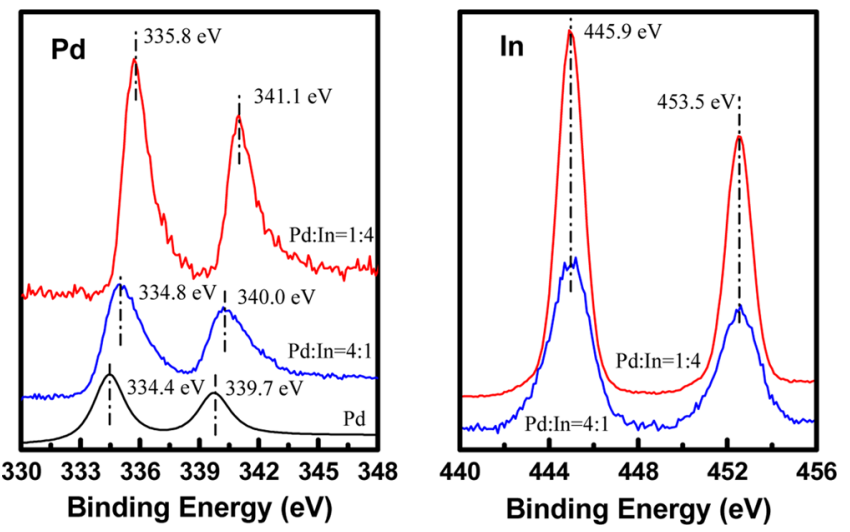

Figure 4. XPS spectra of $\mathrm{Pd}$ in $\mathrm{Pd} / \mathrm{Al}_{2} \mathrm{O}_{3}, \mathrm{Pd}_{4}-\mathrm{In}_{1} / \mathrm{Al}_{2} \mathrm{O}_{3}$, and $\mathrm{Pd}_{1}-\mathrm{In}_{4} /$ $\mathrm{Al}_{2} \mathrm{O}_{3}$ catalysts and XPS spectra of In for $\mathrm{Pd}_{4}-\mathrm{In}_{1} / \mathrm{Al}_{2} \mathrm{O}_{3}$ and $\mathrm{Pd}_{1}-\mathrm{In}_{4} /$ $\mathrm{Al}_{2} \mathrm{O}_{3}$ catalysts.

content. This proved that a Pd-In alloy was formed and that In could change the chemical environment of $\mathrm{Pd}^{33}$

Effect of Different Parameters on $\mathrm{Pd}_{1}-\mathrm{In}_{4} / \mathrm{Al}_{2} \mathrm{O}_{3}$ Efficiency. Figure $\mathrm{S} 2$ explores the influence of different parameters such as catalyst dosage, solution $\mathrm{pH}$, and current density on the electroreduction performance of $\mathrm{Pd}_{1}-\mathrm{In}_{4} / \mathrm{Al}_{2} \mathrm{O}_{3}$. The bromate removal rate increased with the dosage of $\mathrm{Pd}_{1}-\mathrm{In}_{4} /$ $\mathrm{Al}_{2} \mathrm{O}_{3}(0.2-1.0 \mathrm{~g} / \mathrm{L})$ and then maintained a steady level when the catalyst concentration was further increased to $1.5 \mathrm{~g} / \mathrm{L}$, while the effect of initial solution $\mathrm{pH}$ was not significant and almost $100 \%$ of the bromate was degraded after reaction for $25 \mathrm{~min}$. The weak $\mathrm{pH}$ effect reflects that the electrocatalytic reduction of bromate with the $\mathrm{Pd}_{1}-\mathrm{In}_{4} / \mathrm{Al}_{2} \mathrm{O}_{3}$ can be performed under a wide $\mathrm{pH}$ range. Since the generation of atomic $\mathrm{H}^{*}$ through the Volmer reaction is favored in acid solutions, ${ }^{34}$ the high efficiency of 

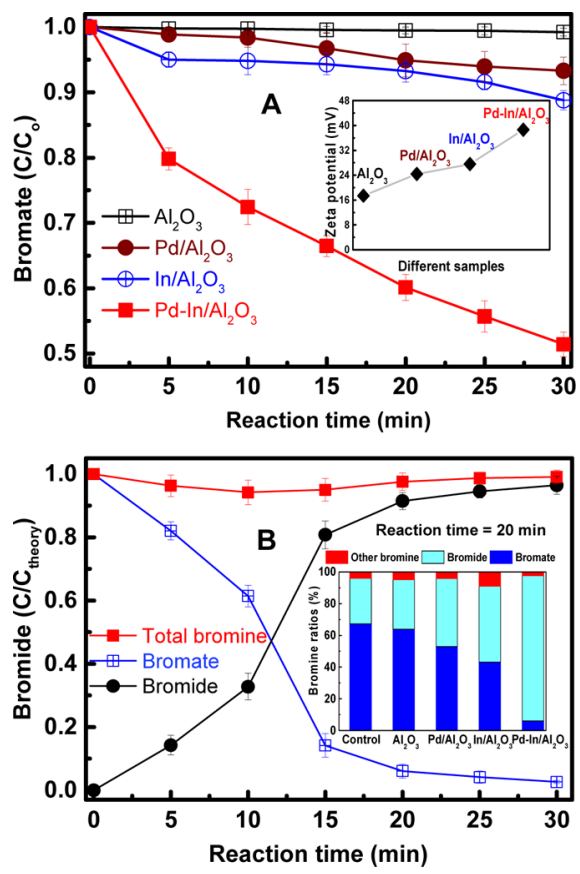

Figure 5. (A) The adsorption of bromate using different catalysts without applying any electrochemical potential (catalyst dosage $=$ $1.0 \mathrm{~g} / \mathrm{L}$, initial bromate concentration $=100 \mu \mathrm{g} / \mathrm{L}, 2 \mathrm{mM} \mathrm{Na}_{2} \mathrm{SO}_{4}$, $\mathrm{pH}=7.0$ ). Inset shows the surface zeta potentials of different catalysts at $\mathrm{pH}$ 7.0. (B) Bromine mass balance during the electrochemical reduction process (catalyst dosage $=1.0 \mathrm{~g} / \mathrm{L}$, initial bromate concentration $=$ $10 \mathrm{mg} / \mathrm{L}, 2 \mathrm{mM} \mathrm{Na}_{2} \mathrm{SO}_{4}, \mathrm{pH}=7.0$, current density $=2 \mathrm{~mA} / \mathrm{cm}^{2}$ ). Inset shows the bromine balance with different catalysts under the same other conditions.

bromate removal at neutral $\mathrm{pH}$ indicated that the contribution of atomic $\mathrm{H}^{*}$ to bromate reduction is likely to be insignificant. In addition, the influence of current density on the $\mathrm{Pd}_{1}-\mathrm{In}_{4} / \mathrm{Al}_{2} \mathrm{O}_{3}$ efficiency was also examined at 0.3 to $1.2 \mathrm{~mA} / \mathrm{cm}^{2}$. The reduction rate markedly increased with current density ( 0.3 to $0.9 \mathrm{~mA} / \mathrm{cm}^{2}$ ) and then remained constant at a higher current of $1.2 \mathrm{~mA} / \mathrm{cm}^{2}$. Higher current density will produce more available electrons, ${ }^{35}$ leading to higher efficiency in bromate reduction. The similar efficiency of $\mathrm{Pd}_{1}-\mathrm{In}_{4} / \mathrm{Al}_{2} \mathrm{O}_{3}$ at 1.2 and $0.9 \mathrm{~mA} / \mathrm{cm}^{2}$ should be attributed to the limitation of active sites in the catalyst, interfering with the electron transfer to bromate.

Proposed Mechanism of Bromate Reduction on $\mathrm{Pd}_{1}-$ $\mathrm{In}_{4} / \mathrm{Al}_{2} \mathrm{O}_{3}$. Figure $5 \mathrm{~A}$ depicts bromate removal by adsorption over different materials without the addition of applied current. Compared with $\mathrm{Al}_{2} \mathrm{O}_{3}$ without bromate adsorption, only $7 \%$ and $11 \%$ of bromate was adsorbed on $\mathrm{Pd} / \mathrm{Al}_{2} \mathrm{O}_{3}$ and $\mathrm{In} / \mathrm{Al}_{2} \mathrm{O}_{3} \cdot \mathrm{Pd}_{1}-$ $\mathrm{In}_{4} / \mathrm{Al}_{2} \mathrm{O}_{3}$ exhibited the highest adsorption capacity, and $48.6 \%$ of bromate could be removed under the same conditions. However, there were no bromide species detected during the adsorption process. This was because of the much higher zeta potential of $\mathrm{Pd}_{1}-\mathrm{In}_{4} / \mathrm{Al}_{2} \mathrm{O}_{3}$ than the other three catalysts at neutral $\mathrm{pH}$ (inset of Figure 5A). Hence, the more positive surface charge facilitated the adsorption of the negatively charged bromate on $\mathrm{Pd}_{1}-\mathrm{In}_{4} / \mathrm{Al}_{2} \mathrm{O}_{3}$. After the addition of applied current, the removed bromate was almost completely reduced to bromide for all the tested catalysts (inset of Figure 5B). For example, the sum of bromate and bromide at $30 \mathrm{~min}$ accounted for $99.1 \%$ of the total bromine added into the reactor for $\mathrm{Pd}_{1}-\mathrm{In}_{4} / \mathrm{Al}_{2} \mathrm{O}_{3}$, which indicated that the decreased bromate was completely converted into bromide. Regarding the slight decrease in the sum of bromate and bromide during the reaction process (5-20 $\mathrm{min})$, this was due to the formation of other bromine species such as $\mathrm{BrO}_{2}^{-}, \mathrm{HBrO}_{2}$, and $\mathrm{HOBr} / \mathrm{OBr}^{-} .{ }^{36}$ However, they were finally converted into bromide, since the mass balance of total bromine was recovered at $30 \mathrm{~min}$.

The electroreduction mechanism of bromate by $\mathrm{Pd}_{1}-\mathrm{In}_{4} /$ $\mathrm{Al}_{2} \mathrm{O}_{3}$ was further investigated because direct electron transfer and atomic $\mathrm{H}^{*}$ may be both involved in the reaction process. ${ }^{37,38}$ As shown in Figure 6A, nine characteristic peaks of DMPO- $\mathrm{H}^{39}$ with strong intensity were detected by ESR in the presence of catalyst compared with the control experiment (no catalyst). This confirmed that atomic $\mathrm{H}^{*}$ was indeed produced and involved in the bromate reduction process. However, the peak intensity of DMPO-H was similar for $\mathrm{Pd} / \mathrm{Al}_{2} \mathrm{O}_{3}, \mathrm{In} / \mathrm{Al}_{2} \mathrm{O}_{3}$, and $\mathrm{Pd}_{1}-\mathrm{In}_{4} / \mathrm{Al}_{2} \mathrm{O}_{3}$, which indicated that the introduction of In had no positive effect on the atomic $\mathrm{H}^{*}$ generation for $\mathrm{Pd}_{1}-\mathrm{In}_{4} /$ $\mathrm{Al}_{2} \mathrm{O}_{3}$. tert- $\mathrm{BuOH}$ is a quenching reagent toward atomic $\mathrm{H}^{*}$; therefore its influence on bromate electroreduction was also studied. As shown in Figure 6B and C, a significant inhibition of bromate removal in the presence of tert- $\mathrm{BuOH}(10 \mathrm{mM})$ was
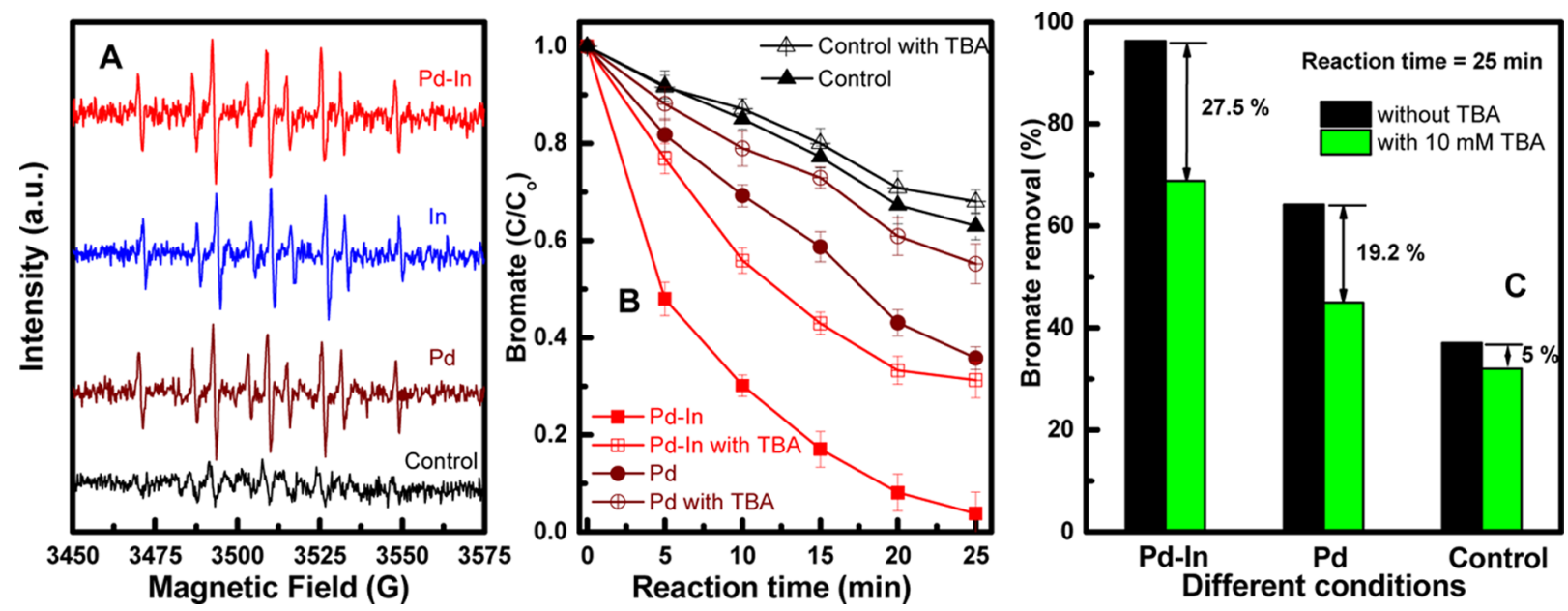

Figure 6. (A) The DMPO spin-trapping ESR spectra with different catalysts at a current density of $0.9 \mathrm{~mA} / \mathrm{cm}^{2}$. (B) Electrochemical reduction of bromate in different systems with various $\mathrm{C}_{4} \mathrm{H}_{10} \mathrm{O}$ concentrations (catalyst dosage $=1.0 \mathrm{~g} / \mathrm{L}$, initial bromate concentration $=100 \mu \mathrm{g} / \mathrm{L}, 2 \mathrm{mM} \mathrm{Na} \mathrm{SO}_{4}$, $\mathrm{pH}=7.0$, current density $\left.=0.9 \mathrm{~mA} / \mathrm{cm}^{2}\right)$. (C) Bromate removal with and without $\mathrm{C}_{4} \mathrm{H}_{10} \mathrm{O}$ under different conditions at a reaction time of 20 min. 
observed for $\mathrm{Pd} / \mathrm{Al}_{2} \mathrm{O}_{3}$ and $\mathrm{Pd}_{1}-\mathrm{In}_{4} / \mathrm{Al}_{2} \mathrm{O}_{3}$ catalysts with efficiency decreases of $27.5 \%$ and $19.2 \%$, while the negative effect of tert-BuOH was not significant for the control experiment, with only $5 \%$ inhibition. It can be speculated that the $37 \%$ bromate removal in the control should come from direct electron transfer, and both direct electron transfer and indirect atomic $\mathrm{H}^{*}$ reduction contributed to the bromate removal in the presence of catalysts. The higher contribution of direct electron reduction to bromate removal in the presence of catalysts (especially for $\mathrm{Pd}_{1}-\mathrm{In}_{4} / \mathrm{Al}_{2} \mathrm{O}_{3}$ ) was attributed to the increase of electron transfer to the adsorbed bromate due to the unique property of $\mathrm{Pd}$ metal in trapping electrons and the promoting effect of In within the catalyst. Since dissolved oxygen (DO) could compete with target pollutants for the reaction sites and then suppress the removal efficiency toward pollutants, ${ }^{38} \mathrm{DO}$ in the reaction system was removed by $\mathrm{N}_{2}$ sparging, and its concentration was reduced from 7.42 to $0.80 \mathrm{mg} / \mathrm{L}$. As shown in Figure 7, the bromate reduction efficiency

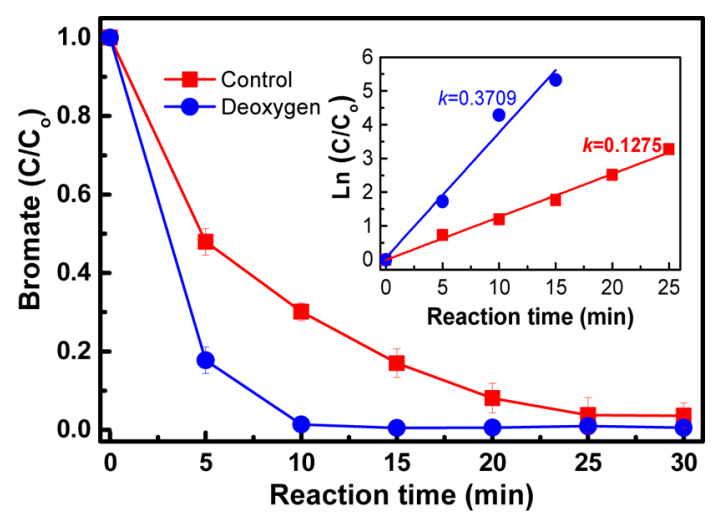

Figure 7. Effect of DO on electrochemical reduction of bromate in the reactor with $\mathrm{Pd}_{1}-\mathrm{In}_{4} / \mathrm{Al}_{2} \mathrm{O}_{3}$ catalyst (catalyst dosage $=1.0 \mathrm{~g} / \mathrm{L}$, initial bromate concentration $=100 \mu \mathrm{g} / \mathrm{L}, 2 \mathrm{mM} \mathrm{Na}_{2} \mathrm{SO}_{4}, \mathrm{pH}=7.0$, current density $\left.=0.9 \mathrm{~mA} / \mathrm{cm}^{2}\right)$.

was greatly enhanced when DO was removed, and the reaction constant was 3 times higher than that in the presence of DO $\left(0.3709 \mathrm{~min}^{-1}\right.$ vs $\left.0.1275 \mathrm{~min}^{-1}\right)$. This indicated the competition effects with oxygen for reactive sites on the catalyst by consuming both the electrons and atomic $\mathrm{H}^{*}$. As shown in Figure $\mathrm{S} 3$, a reaction mechanism for bromate reduction over $\mathrm{Pd}_{1}-\mathrm{In}_{4} / \mathrm{Al}_{2} \mathrm{O}_{3}$ was proposed based on all the experimental results. Bromate was first adsorbed on $\mathrm{Pd}_{1}-\mathrm{In}_{4} / \mathrm{Al}_{2} \mathrm{O}_{3}$, and after the addition of applied current, electrons and atomic $\mathrm{H}^{*}$ were both generated in the reaction system. The direct reduction of bromate by electrons played a more important role in bromate removal in the presence of $\mathrm{Pd}_{1}-\mathrm{In}_{4} / \mathrm{Al}_{2} \mathrm{O}_{3}$ catalyst, probably due to the enhancement of electron transfer by $\mathrm{Pd}-\mathrm{In}$ within the catalyst. Compared to the other catalysts such as $\mathrm{Pd}-\mathrm{Cu}$, $\mathrm{Pd}-\mathrm{Sn}$, and $\mathrm{Pd}-\mathrm{Bi}$, the higher activity of $\mathrm{Pd}_{1}-\mathrm{In}_{4} / \mathrm{Al}_{2} \mathrm{O}_{3}$ toward bromate reduction may be due to two aspects: (i) the improved adsorption of bromate on the catalyst and (ii) the enhanced transfer of electrons and atomic $\mathrm{H}^{*}$ from catalyst to bromate.

\section{ASSOCIATED CONTENT}

\section{S Supporting Information}

The Supporting Information is available free of charge on the ACS Publications website at DOI: 10.1021/acs.est.6b02822.

Additional experimental details and data (PDF)

\section{AUTHOR INFORMATION}

\section{Corresponding Author}

*Tel.: +86 10 62849160. Fax: +86 10 62849160. E-mail:

liuruiping@rcees.ac.cn.

\section{Notes}

The authors declare no competing financial interest.

\section{ACKNOWLEDGMENTS}

This work was supported by the National Natural Science Foundation of China (Nos. 51478455, 51438011, 51422813).

\section{REFERENCES}

(1) Weinberg, H. S.; Delcomyn, C. A.; Unnam, V. Bromate in chlorinated drinking waters: Occurrence and implications for future regulation. Environ. Sci. Technol. 2003, 37, 3104-3110.

(2) Butler, R.; Godley, A.; Lytton, L.; Cartmell, E. Bromate environmental contamination: review of impact and possible treatment. Crit. Rev. Environ. Sci. Technol. 2005, 35, 193-217.

(3) Liu, J.; Yu, J.; Li, D.; Zhang, Y.; Yang, M. Reduction of bromate in a biological activated carbon filter under high bulk dissolved oxygen conditions and characterization of bromate-reducing isolates. Biochem. Eng. J. 2012, 65, 44-50.

(4) Asami, M.; Aizawa, T.; Morioka, T.; Nishijima, W.; Tabata, A.; Magara, Y. Bromate removal during transition from new granular activated carbon (GAC) to biological activated carbon (BAC). Water Res. 1999, 33, 2797-2804.

(5) Zhao, X.; Liu, H.; Shen, Y.; Qu, J. Photocatalytic reduction of bromate at $\mathrm{C}_{60}$ modified $\mathrm{Bi}_{2} \mathrm{MoO}_{6}$ under visible light irradiation. Appl. Catal., B 2011, 106, 63-68.

(6) Listiarini, K.; Tor, J. T.; Sun, D. D.; Leckie, J. O. Hybrid coagulation-nanofiltration membrane for removal of bromate and humic acid in water. J. Membr. Sci. 2010, 365, 154-159.

(7) Li, T.; Chen, Y.; Wan, P.; Fan, M.; Yang, X. J. Chemical degradation of drinking water disinfection byproducts by millimeter-sized particles of iron-silicon and magnesium-aluminum alloys. J. Am. Chem. Soc. 2010, 132, 2500-2501.

(8) Kirisits, M. J.; Snoeyink, V. L.; Inan, H.; Chee-Sanford, J. C.; Raskin, L.; Brown, J. C. Water quality factors affecting bromate reduction in biologically active carbon filters. Water Res. 2001, 35, 891900.

(9) Zhou, J.; Wu, K.; Wang, W.; Han, Y.; Xu, Z.; Wan, H.; Zheng, S.; $\mathrm{Zhu}, \mathrm{D}$. Simultaneous removal of monochloroacetic acid and bromate by liquid phase catalytic hydrogenation over $\mathrm{Pd} / \mathrm{Ce}_{1-\mathrm{x}} \mathrm{Zr}_{\mathrm{x}} \mathrm{O}_{2}$. Appl. Catal., B 2015, 162, 85-92.

(10) Chen, H.; Xu, Z.; Wan, H.; Zheng, J.; Yin, D.; Zheng, S. Aqueous bromate reduction by catalytic hydrogenation over $\mathrm{Pd} / \mathrm{Al}_{2} \mathrm{O}_{3}$ catalysts. Appl. Catal., B 2010, 96, 307-313.

(11) Wang, Y.; Liu, J.; Wang, P.; Werth, C. J.; Strathmann, T. J. Palladium nanoparticles encapsulated in core-shell silica: A structured hydrogenation catalyst with enhanced activity for reduction of oxyanion water pollutants. ACS Catal. 2014, 4, 3551-3559.

(12) Ding, L.; Li, Q.; Cui, H.; Tang, R.; Xu, H.; Xie, X.; Zhai, J. Electrocatalytic reduction of bromate ion using a polyaniline-modified electrode: An efficient and green technology for the removal of $\mathrm{BrO}_{3}{ }^{-}$in aqueous solutions. Electrochim. Acta 2010, 55, 8471-8475.

(13) Mao, R.; Zhao, X.; Lan, H.; Liu, H.; Qu, J. Graphene-modified Pd/ $\mathrm{C}$ cathode and $\mathrm{Pd} / \mathrm{GAC}$ particles for enhanced electrocatalytic removal of bromate in a continuous three-dimensional electrochemical reactor. Water Res. 2015, 77, 1-12.

(14) Zhao, X.; Liu, H.; Li, A.; Shen, Y.; Qu, J. Bromate removal by electrochemical reduction at boron-doped diamond electrode. Electrochim. Acta 2012, 62, 181-184.

(15) Kishimoto, N.; Matsuda, N. Bromate ion removal by electrochemical reduction using an activated carbon felt electrode. Environ. Sci. Technol. 2009, 43, 2054-2059.

(16) Wei, L. Y.; Guo, S. H.; Yan, G. X.; Chen, C. M.; Jiang, X. Y. Electrochemical pretreatment of heavy oil refinery wastewater using a 
three-dimensional electrode reactor. Electrochim. Acta 2010, 55, 86158620.

(17) Kong, W. P.; Wang, B.; Ma, H. Z.; Gu, L. Electrochemical treatment of anionic surfactants in synthetic wastewater with threedimensional electrodes. J. Hazard. Mater. 2006, 137, 1532-1537.

(18) Mascia, M.; Vacca, A.; Palmas, S. Fixed bed reactors with three dimensional electrodes for electrochemical treatment of waters for disinfection. Chem. Eng. J. 2012, 211-212, 479-487.

(19) Chaplin, B. P.; Reinhard, M.; Schneider, W. F.; Schüth, C.; Shapley, J. R.; Strathmann, T. J.; Werth, C. J. Critical review of Pd-based catalytic treatment of priority contaminants in water. Environ. Sci. Technol. 2012, 46, 11469-11470.

(20) Ksar, F.; Ramos, L.; Keita, B.; Nadjo, L.; Beaunier, P.; Remita, H. Bimetallic palladium-gold nanostructures: application in ethanol oxidation. Chem. Mater. 2009, 21, 3677-3683.

(21) Spee, M. P.; Boersma, J.; Meijer, M. D.; Slagt, M. Q.; van Koten, G.; Geus, J. W. Selective liquid-phase semihydrogenation of functionalized acetylenes and propargylic alcohols with silica-supported bimetallic palladium-copper catalysts. J. Org. Chem. 2001, 66, 16471656.

(22) Son, S. U.; Jang, Y.; Park, J.; Na, H. B.; Park, H. M.; Yun, H. J.; Lee, J.; Hyeon, T. Designed synthesis of atom-economical Pd/Ni bimetallic nanoparticle-based catalysts for sonogashira coupling reactions. J. Am. Chem. Soc. 2004, 126, 5026-5027.

(23) Yoshinaga, Y.; Akita, T.; Mikami, I.; Okuhara, T. Hydrogenation of nitrate in water to nitrogen over $\mathrm{Pd}-\mathrm{Cu}$ supported on active carbon. $J$. Catal. 2002, 207, 37-45.

(24) Hou, W.; Dehm, N. A.; Scott, R. W. Alcohol oxidations in aqueous solutions using $\mathrm{Au}, \mathrm{Pd}$, and bimetallic AuPd nanoparticle catalysts. J. Catal. 2008, 253, 22-27.

(25) Wenkin, M.; Ruiz, P.; Delmon, B.; Devillers, M. The role of bismuth as promoter in $\mathrm{Pd}-\mathrm{Bi}$ catalysts for the selective oxidation of glucose to gluconate. J. Mol. Catal. A: Chem. 2002, 180, 141-159.

(26) Wang, Y.; Qu, J.; Wu, R.; Lei, P. The electrocatalytic reduction of nitrate in water on $\mathrm{Pd} / \mathrm{Sn}$-modified activated carbon fiber electrode. Water Res. 2006, 40, 1224-1232.

(27) Shao, M. H.; Sasaki, K.; Adzic, R. R. Pd-Fe nanoparticles as electrocatalysts for oxygen reduction. J. Am. Chem. Soc. 2006, 128, $3526-3527$.

(28) Gavagnin, R.; Biasetto, L.; Pinna, F.; Strukul, G. Nitrate removal in drinking waters: the effect of tin oxides in the catalytic hydrogenation of nitrate by $\mathrm{Pd} / \mathrm{SnO}_{2}$ catalysts. Appl. Catal., B 2002, 38, 91-99.

(29) Davie, M. G.; Shih, K.; Pacheco, F. A.; Leckie, J. O.; Reinhard, M. Palladium-indium catalyzed reduction of $\mathrm{N}$-nitrosodimethylamine: indium as a promoter metal. Environ. Sci. Technol. 2008, 42, 3040-3046.

(30) Yuranova, T.; Kiwi-Minsker, L.; Franch, C.; Palomares, A. E.; Armenise, S.; García-Bordejé, E. Nanostructured catalysts for the continuous reduction of nitrates and bromates in water. Ind. Eng. Chem. Res. 2013, 52, 13930-13937.

(31) An, W.; Hong, J. K.; Pintauro, P. N. Current efficiency for soybean oil hydrogenation in a solid polymer electrolyte reactor. J. Appl. Electrochem. 1998, 28, 947-954.

(32) Harris, I. R.; Norman, M.; Bryant, A. W. A study of some palladium-indium, platinum-indium and platinum-tin alloys. J. LessCommon Met. 1968, 16, 427-440.

(33) Marchesini, F. A.; Irusta, S.; Querini, C.; Miró, E. Spectroscopic and catalytic characterization of $\mathrm{Pd}-\mathrm{In}$ and $\mathrm{Pt}-\mathrm{In}$ supported on $\mathrm{Al}_{2} \mathrm{O}_{3}$ and $\mathrm{SiO}_{2}$, active catalysts for nitrate hydrogenation. Appl. Catal., A 2008, $348,60-70$.

(34) Gennero de Chialvo, M. R.; Chialvo, A. C. Kinetics of hydrogen evolution reaction with Frumkin adsorption: re-examination of the Volmer-Heyrovsky and Volmer-Tafel routes. Electrochim. Acta 1998, 44, 841-851.

(35) Mao, X. H.; Ciblak, A.; Amiri, M.; Alshawabkeh, A. N. Redox control for electrochemical dechlorination of trichloroethylene in bicarbonate aqueous media. Environ. Sci. Technol. 2011, 45, 6517-6523. (36) Qu, J.; Zou, X.; Liu, B.; Dong, S. Assembly of polyoxometalates on carbon nanotubes paste electrode and its catalytic behaviors. Anal. Chim. Acta 2007, 599, 51-57.
(37) Li, T.; Farrell, J. Reductive dechlorination of trichloroethene and carbon tetrachloride using iron and palladized-iron cathodes. Environ. Sci. Technol. 2000, 34, 173-179.

(38) Xie, W. J.; Yuan, S. H.; Mao, X. H.; Hu, W.; Liao, P.; Tong, M.; Alshawabkeh, A. N. Electrocatalytic activity of Pd-loaded $\mathrm{Ti} / \mathrm{TiO}_{2}$ nanotubes cathode for TCE reduction in groundwater. Water Res. 2013, 47, 3573-3582.

(39) Mao, R.; Li, N.; Lan, H.; Zhao, X.; Liu, H.; Qu, J.; Sun, M. Dechlorination of trichloroacetic acid using a noble metal-free graphene-Cu foam electrode via direct cathodic reduction and atomic H*. Environ. Sci. Technol. 2016, 50, 3829-3837. 